\title{
Designing of Mikrokontroler E-Learning Course: Using Arduino and TinkerCad
}

\author{
Direstu Amalia ${ }^{1}$, IGAAMOka ${ }^{2}$, Virma Septiani $^{3}$, M Rafli Fazal $^{4}$ \\ ${ }^{1,2,3,4}$ Politeknik Penerbangan Palembang \\ * e-mail: direstu@poltekbangplg.ac.id
}

\begin{abstract}
During the Covid-19 pandemic, education and training activities began to shift to online classes. The problem is, the training carried out is only limited to theory-based training, not practical training. The current situation raises new possibilities in changing the learning method to fully online classes, with the character of vocational education, namely student-centered learning. The expected advantage is that education can be applied anywhere, this article explains how education providers develop research and development with the ADDIE method to analyze curriculum and learning models by promoting project-based learning methods where students are expected to be able to develop actively in learning. The TRBU Study Program designed the Arduino IDE microcontroller online training using free TinkerCad simulation with asynchronous learning materials through the LMS and supported by online classes using the zoom application. The results showed that $42.9 \%$ of students have high interest in online workshop and $92.9 \%$ agree that this online course needs to be re-implemented.
\end{abstract}

Keywords: e-learning, Microcontroller, Arduino, TinkerCad, Politeknik Penerbangan Palembang

(1) Licensees may copy, distribute, display and perform the work and make derivative works and remixes based on it only if they give the author or licensor the credits (attribution) in the manner specified by these. Licensees may copy, distribute, display, and perform the work and make derivative works and remixes based on it only for non-commercial purposes.

\section{INTRODUCTION}

Airport Engineering Technology (TRBU) applied undergraduate study program, must prepare their lecturers, educators and graduates to face industry 4.0 challenges, one of which are: 1) Internet of Things (IoT) and 2) Robotics Technology. The era of the internet of things (Wikipedia, 2020) can be called an era in which one device can communicate or give orders to other equipment / devices via an internet connection, even though it is not from one manufacturer. It is often found in "smart home" products, especially devices and equipment applied to: lamps, thermostats, surveillance cameras, etc.

\section{Airport 4.0}

Based on forecast (research and markets, 2020), the smart airport market is projected to grow from USD 2.2 billion in 2019 to USD 6.4 billion in 2025 , with a CAGR of $19.8 \%$ over the forecast period. The growth of the smart airport market is expected to experience increased with the use of self-service technology and the growing need for real-time information. Technological developments and innovations in the field of electronics and control systems, mechanical systems, robotics, which are often referred to as mechatronics, are the main factors in the realization of smart airports. This new experience offering an endto-end integration of information from departure to arrival at the destination airport. Several technologies that have been implemented at the airport, such as: check-in facilities, baggage and cargo handling, air traffic management, communication system and ground handling. Data (Mordor Intelligence, 2020) showing that technological developments at airports directly have a positive impact on market developments with 
the largest passenger growth in the AsiaPacific Region, with China as the highest in the world at $35 \%$.

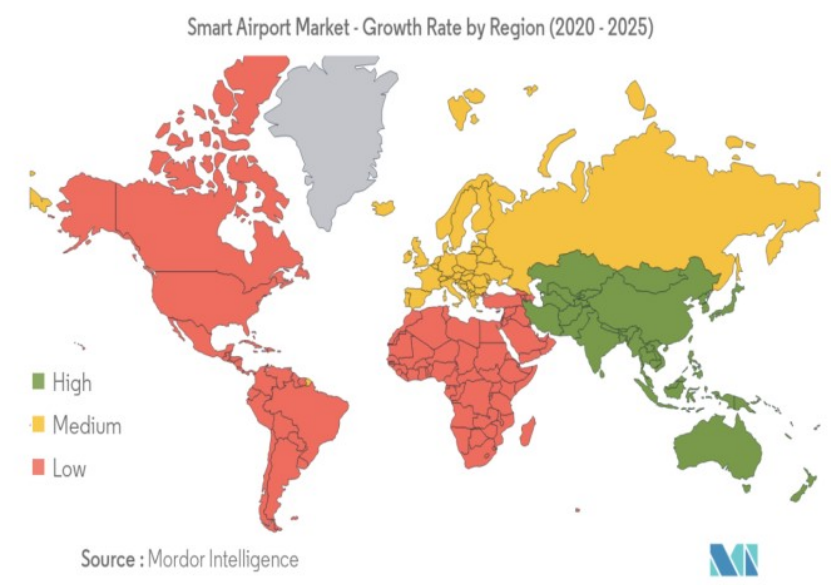

Figure 1. Smart Airport Growth Rate By Region (Intelligence, 2020) (Research and Markets, 2020)

\section{Education in Covid-19 Pandemic Era}

Education cannot wait until the Covid-19 pandemic ends. By the end of March, 95\% of colleges had undertaken learning from home. Of these, $98.2 \%$ did online learning, less than $2 \%$ did other forms of learning (Nizam, 2020). In the industrial era 4.0 as well as the current Covid-19 pandemic, education has become more complex so that a new way of implementation is needed, one way is to implement e-learning-based education. In the current situation of adapting to new habits, we are advised to limit the crowd and keep our distance, and to limit of room capacity by $50 \%$. The application of this new habit, of course, will have an impact on the learning process, especially the duration.

\section{Training of Microcontroller Arduino IDE}

The microcontroller is also called an embedded smart system to control equipment using a digital programming language. The microcontroller itself will be one of the competencies that must be taught in the Electronic and Digital Engineering material in the TRBU study program. The microcontroller training carried out is based on Arduino Uno, Arduino Uno is an open-source microcontroller board based on the Microchip ATmega328P microcontroller and developed by Arduino (Arduino, 2015). (Nizam, 2020)The Arduino board can be programmed according to design needs using the " $\mathrm{C}$ " programming language, arduino programming is carried out in Arduino software called Sketches (Arduino, 2015). The simulation of programming and assembly of electronic circuits on the Arduino board online is done using the TinkerCad, TinkerCad is an opensource website that allows you to do basic electronic circuit practicum.

Microcontroller learning is closely related to practicum implementation as a form of learning, in the curriculum set in the TRBU study program, this material will be included in the initial semester in electronics and digital courses. Students are given a learning material and will spend a lot of activities in the digital electronics laboratory. For this reason, the blended learning method with the studentcentered learning model is an option that is expected to be able to replace face-to-face class and most of the practicums in microcontroller laboratories. With the support of suitable curriculum, the purpose of this online arduino microcontroller learning should aims to 1) maximize Arduino programming learning through e-learning media with a practical material approach; 2) students can learn independently anywhere and anytime; 3 ) activities are student-based learning oriented as it a character of vocational education.

\section{METHODS}

The microcontroller training plan for conducted at the Politeknik Penerbangan Palembang, and designed since the end of June 2020 using the model of education research and development ADDIE (Dick \& Carey, 2005). In this article, it will be explained how the implementation of microcontroller training tested using e-learning by involving 20 students with different educational backgrounds. Data collection using an literature study, interview and observation method of educational trend. This activity will be carried out using free media such as: google drive for material storage, whatsapp, zoom meeting application, tinkerCad website, microcontroller Arduino device as an independent practicum tool, Arduino sketches and google form and worksheet for making practicum reports. 


\section{RESULT AND DISCUSSIONS}

\section{Learning Development}

The ADDIE development model (Dick \& Carey, 2005) consists of five stages: Analysis, Design, Development, Implementation, and Evaluation. The ADDIE development model was chosen because it includes all the components in other media development models. The Arduino IDE microcontroller programming material is one of the practical materials that will be taught in two courses in the first semester, namely: 1) Basic Information Technology and 2) Electronics and Digital according to the TRBU 2020 curriculum. learning. In addition, this Arduino microcontroller material requires high reasoning. To facilitate the delivery of the material and the absorption of the material, a medium is needed that can help students carry out simulations and independent exercises that ultimately make it easier for students and stimulate students to learn actively.

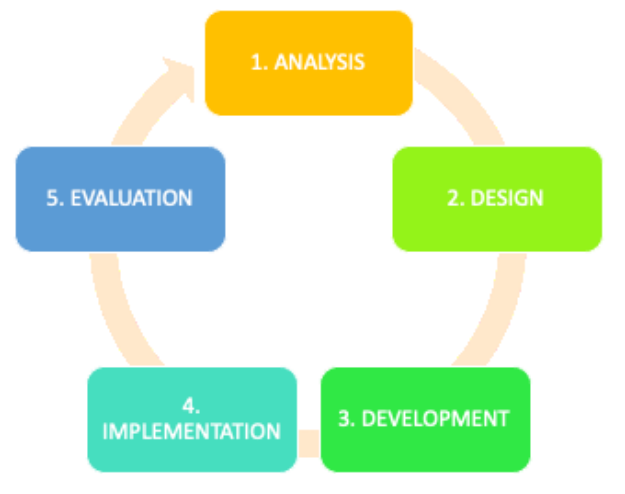

Figure 2. Steps of ADDIE Learning Development Model (Dick \& Carey, 2005)

1). Analysis: This process is carried out by observing the use of learning media. So far, the practical learning media implemented is faceto-face in the classroom with a teachercentered learning model. It is necessary to develop a new form of learning that is more interactive and encourages the creation of student-centered learning.

2) Design: At this stage a curriculum and media are prepared which are expected to accommodate the arduino microcontroller online practicum activities. TinkerCad.com media was chosen as a suitable learning tool for the implementation of simulations. The character of online learning is practical and easy to understand, this microcontroller online learning is also intended for beginners, so it is necessary to pack a simple curriculum that is easy to understand and practice independently. Through interviews with experienced teaching resources, as well as through literacy studies of the Arduino IDE material, the following materials are obtained:

Table 1. Training Curriculum

\begin{tabular}{|c|c|c|c|}
\hline Day & Modul & $\begin{array}{l}\text { Duration } \\
\text { (Hours) }\end{array}$ & Material \\
\hline $\begin{array}{c}\text { Day } \\
1\end{array}$ & $\begin{array}{l}\text { Modul 1: } \\
\text { Arduino Board } \\
\text { \& Software, } \\
\text { Structure of } \\
\text { Arduino } \\
\text { Programme }\end{array}$ & 3 & $\begin{array}{l}\text { a. Aim } \\
\text { b. Tools programme of } \\
\text { Arduino; } \\
\text { c. Structure of Arduino } \\
\text { programme } \\
\text { d. Practicum Exercise }\end{array}$ \\
\hline $\begin{array}{c}\text { Day } \\
2\end{array}$ & $\begin{array}{l}\text { Modul 2: Digital } \\
\text { I/O \& analog I/O }\end{array}$ & 3 & $\begin{array}{l}\text { a. Aim } \\
\text { b. Theoritycal of } \\
\text { Digital and Analog I/O } \\
\text { c. Practicum Exercise }\end{array}$ \\
\hline $\begin{array}{c}\text { Day } \\
3\end{array}$ & $\begin{array}{l}\text { Modul 3: } \\
\text { Interface Sensor } \\
\text { and Actuator }\end{array}$ & 3 & $\begin{array}{l}\text { a. Aim } \\
\text { b. Interface Sensor : } \\
\text { proximity, LDR, } \\
\text { Ultrasonic } \\
\text { c. Actuator Interface : } \\
\text { Servo motor, DC motor } \\
\text { d. Practicum Exercise }\end{array}$ \\
\hline $\begin{array}{c}\text { Day } \\
4\end{array}$ & Final Discussion & 3 & $\begin{array}{l}\text { Discussion related to } \\
\text { exercise modul } 1,2 \text {, } \\
\text { and } 3\end{array}$ \\
\hline
\end{tabular}

The training curriculum must be supported by an e-learning situation in the form of blended-learning without losing the characteristics of vocational education. Characteristics Vocational education (RISTEKDIKTI, 2016) has a graduate profile that is oriented towards the profession and world of work, and has learning outcomes that are: a) Attitude: Professional and standardized; b) Practical knowledge; c) Special skills emphasize the needs of the world of work; d) General skills in being responsible and following 26 standards; e) Curriculum structure: serial based on prerequisite study materials. Referring to the characteristics of vocational education, the implementation of the Arduino microcontroller training is very relevant when using project-based learning methods. 
Table 2. Learning Method and Assignment Form (Amalia, 2020)

\begin{tabular}{l|l}
\hline \multicolumn{2}{c}{$\begin{array}{c}\text { Learning Method and Assignment Form } \\
\text { Project Based Learning }\end{array}$} \\
\hline \multicolumn{1}{c}{ Synchronous } & \multicolumn{1}{c}{ Asynchronous } \\
\hline $\begin{array}{l}\text { Using Zoom Meeting } \\
\text { Apk }\end{array}$ & $\begin{array}{l}\text { A. LMS https: //e- } \\
\text { learning.poltekbang } \\
\text { plg.ac.id/ }\end{array}$ \\
$\begin{array}{l}\text { 1. Presentation by } \\
\text { mentor }\end{array}$ & material in the form of: \\
2. Discussion & 2. Material of training (pdf) \\
3. Simulation using & 3. Student exercise \\
Tinkercad & worksheet: Ms. Office Word \\
& 4. Student evaluation form: \\
& Gform \\
& 9. Link for downloading \\
& Sketches for Arduino \\
& B. Practical \\
& Arduino Uno Starter Kit \\
\end{tabular}

3) Development:

In this process, teaching materials are made according to the curriculum and preparation of learning methods and forms as planned. After the process, then the teaching material validation as intended were carried out. The online simulation media chosen is TinkerCad and the application of the design from Tinkercad is Arduino uno board.

Validation was carried out by material experts and media experts related to material and media releasing aspects (Walid, 2017). Validation by material experts in addition to conducting a feasibility assessment, material and media experts also provide comments and suggestions for improving the media. The results of the validation carried out by material experts and media experts can be seen in the following table:

Table 3. Material Aspect Validation Tabel

\begin{tabular}{lc}
\hline \multicolumn{1}{c}{ Rated Aspect } & $\begin{array}{c}\text { Validator's } \\
\text { assessment }\end{array}$ \\
\hline I. Content Eligibility Components & \\
A. Coverage of material & 4 \\
B. Linkage of basic competencies & 4 \\
1. The relevance of learning objectives & \\
with core competencies / basic & 4 \\
competencies & \\
2. The suitability of the material with \\
basic competencies \\
C. Accuracy of material \\
$\quad$ (truth and accuracy) \\
1. Truth and validity of concepts
\end{tabular}

2. The correctness and accuracy of the theory

II. Serving Components

A. Presentation of learning

1. Encourage students to know the content of learning media

2. Stimulate student involvement /

participation for independent learning

3. Systematic / sequential / clear logic

flow

4. Easy to learn

B. Language Aspects

1. The language used is easy to

understand by students

2. Does not mean double (ambiguous)

Average 3.9

The final validation figure obtained shows that the material being developed is valid and can be implemented.

Table 4. Media Aspect Validation Tabel

\begin{tabular}{lc}
\hline \multicolumn{1}{c}{ Rated Aspect } & $\begin{array}{c}\text { Validator's } \\
\text { Assesment }\end{array}$ \\
\hline $\begin{array}{l}\text { A. Component Eligibility Content } \\
\text { 1. The suitability of learning media to } \\
\text { make it easier for students }\end{array}$ & 4 \\
$\begin{array}{l}\text { 2. Media suitability for individuals / } \\
\text { groups }\end{array}$ & 3 \\
$\begin{array}{l}\text { B. Effectiveness of the media used } \\
\text { 1. Effective and efficient in the } \\
\text { development and use of instructional } \\
\text { media }\end{array}$ & 3 \\
$\begin{array}{l}\text { 2. Be creative in ideas and ideas } \\
\text { C. Media Quality }\end{array}$ & 4 \\
$\begin{array}{l}\text { 1.Maintainable (can be maintained and } \\
\text { managed easily) }\end{array}$ & 4 \\
2.Usability (easy to use and simple in \\
operation) \\
$\begin{array}{l}\text { 3. Compatibility (learning media can be } \\
\text { installed) }\end{array}$ \\
$\begin{array}{l}\text { 4.Reusable (part / all of the learning } \\
\text { media program can be reused for the } \\
\text { development of other learning media) } \\
\text { 5. Communicative (according to the } \\
\text { target and can be accepted with the } \\
\text { wishes of the target) }\end{array}$ \\
\hline \begin{tabular}{l} 
Average \\
\hline
\end{tabular}
\end{tabular}

Based on the table above, the media aspect obtained an average of 3.8, namely the valid category. The suggestions for improvement given by the validator are the addition of an Arduino Software (IDE) 
installation instruction book or video called Sketches, as well as an Arduino circuit simulation video on Tinkercad. So, it can be concluded that the arduino online microcontroller learning media using the Tinkercad simulator can be tested with revision.

4) Implementation:

The implementation step is a continuation of the development stage. The design of learning materials and media was carried out and tested in an initial training attended by 20 employees, not all of whom had electrical education backgrounds. The designed training materials began to be used, and Tinkercad was designated as the Arduino simulation medium.

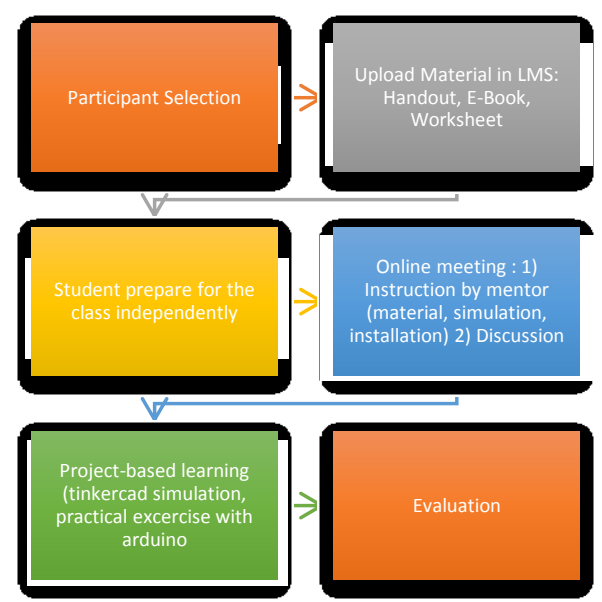

Figure 3. Steps of Implementation Project-Based Learning

The criteria for this training participant are required to have basic knowledge of programming or digital electronics, and or have an interest in robotics or controllers. This is to facilitate the adaptation process for the students. Furthermore, https://lms.poltekbangplg.ac.id/ as an asynchronous learning media to create a course, participant IDs, upload learning materials, as well as conduct evaluations.

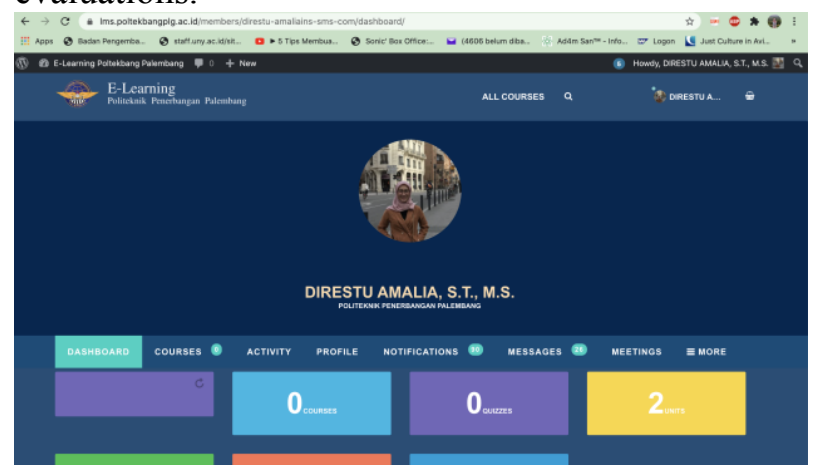

Figure 4. Learning Management System Page

With this learning management system (Politeknik Penerbangan Palembang, 2020), students are required to learn independently by accessing the material in the LMS before the online face-to-face class starts, so that the online class will contain active discussions between mentor and the participants.

Furthermore, students can simulate at https://www.tinkercad.com/ (Arduino Indonesia, 2018)and practice independently by doing work with the arduino starter kit that has been provided and downloading the arduino IDE software to design the program. Download Software Arduino IDE in website address https://www.arduino.cc/en/Main/Software.

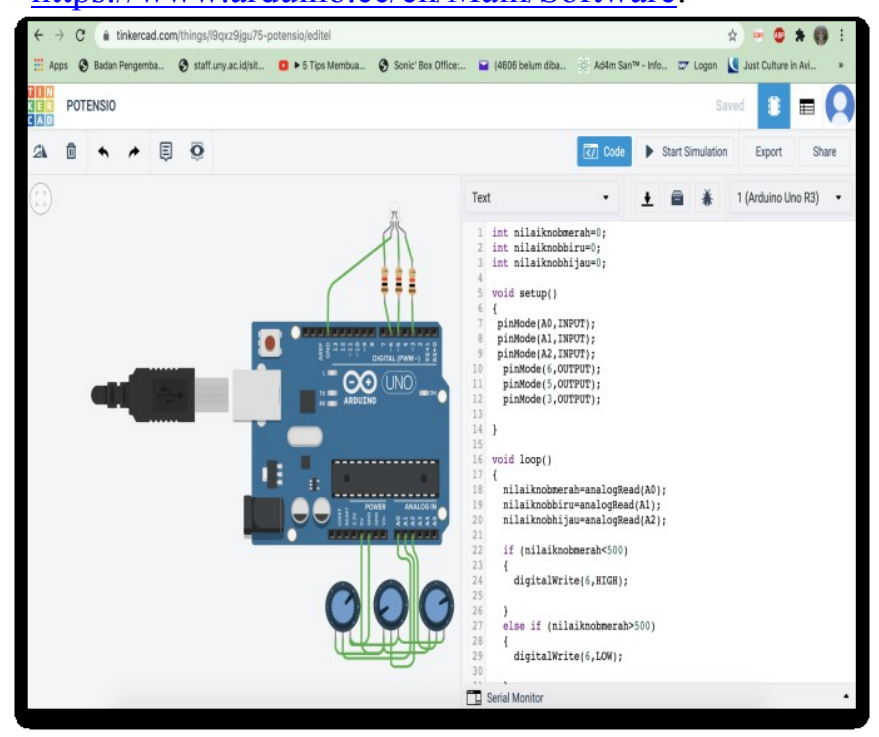

Figure 5. Arduino on Tinkercad.com (tinkercad, 2020)

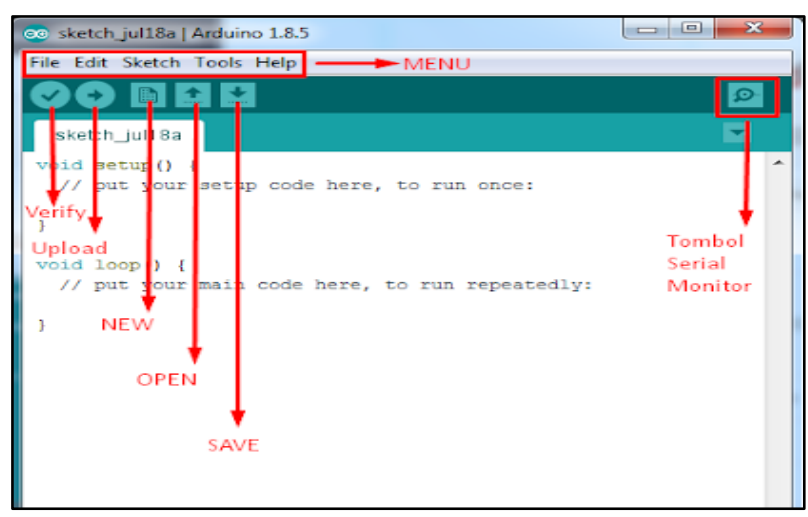

Figure 6. Arduino IDE Software (Arduino Indonesia, 2018)

\section{5) Evaluation:}

The aspect of evaluation in the projectbased learning model is that the evaluation must be carried out thoroughly including the dynamics in the process, determining solutions and the resulting impact on the results of their work. Documents in the form of evidence of tinkercad simulations and 
real designs are data used to carry out evaluations or assessments. Success in doing assignments is a measure of learning achievement.

Table 5. Core Activities of Training

\begin{tabular}{|l|l|}
\hline \multicolumn{1}{|c|}{ Mentor } & \multicolumn{1}{|c|}{ Student } \\
\hline $\begin{array}{l}\text { - The mentor describes an overview of } \\
\text { the problem and its complexity }\end{array}$ & - Students make assembly plans and \\
- The mentors provide consultations to & - Students conduct studies and seek \\
assist students in problem solving. & additional information to find \\
- The mentor conducts literature studies & solutions in design. \\
to provide needed solutions & - Students perform functional analysis. \\
- The mentor examines the results of & - Students create simulations in \\
students' ideas together & Tinkercad \\
- The mentor provides input and & - Students make prototypes with the \\
evaluation for the design study. & Arduino starterkit. \\
- The mentor conducts an assessment of & - Students do trials. \\
work results, processes and possible & - Students fill out a worksheet form \\
developments & - Students submit input on the obstacles \\
- The mentors give appreciation for & experienced \\
student work in the form of & \\
assessments or conclusions. & \\
\hline \multicolumn{2}{|l}{} \\
\hline
\end{tabular}

\section{Students Response Analysis}

After the mentor and students used the learning media, on the last day of training, the organizer was given a questionnaire. This questionnaire aims to see the responses of mentors and students to the arduino uno microcontroller learning media practice using tinkercad.com simulation. From 20 participants there is 14 participants which fulfill the questionnaire, the results of the responses of mentors and students to learning media using online simulations are as follows:

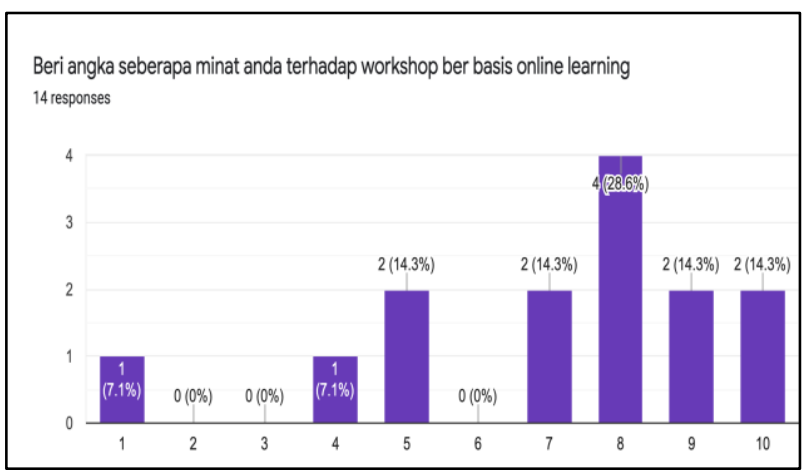

Figure 7. Question of Rate How Interested You are in the Online-Based Learning Workshop

From figure above, it show that most of participants interesting in online-based workshop, with 8 is the biggest number has choosen.

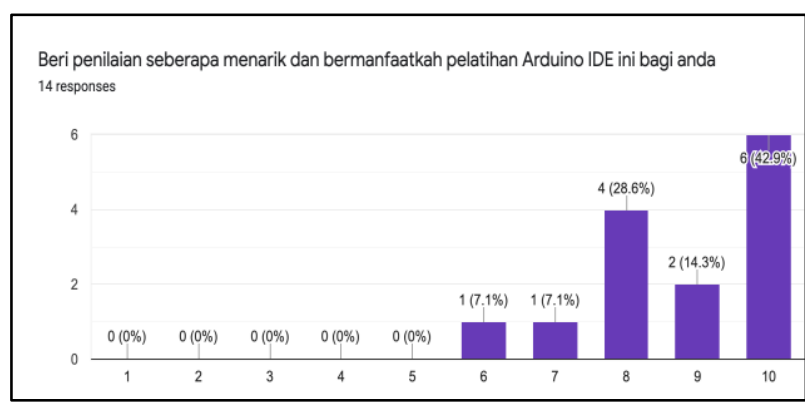

Figure 8. Question of Rate How Interesting and Useful this Arduino IDE Training is For You

From figure above, it show that most of participants think that this mikrokontroler arduino online class is interesting and useful, with $42,9 \%$ votes a highest number 10 .

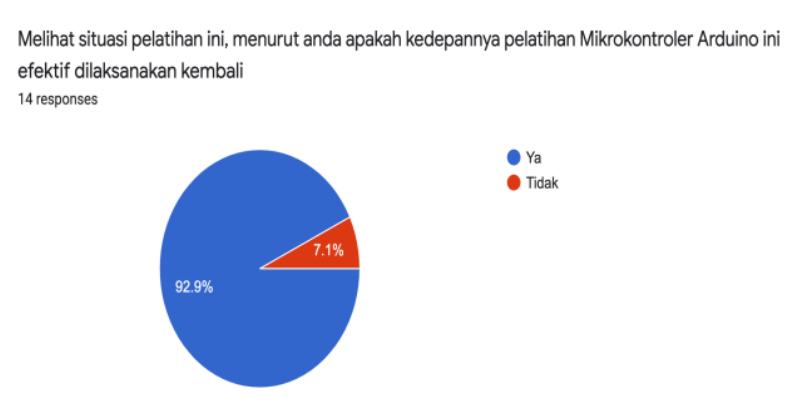

Figure 9. Question of Seeing this Training Situation, Do You Think that in the Future this Arduino Microcontroller Training Will be Effectively Implemented Again

From figure above, it show that $92.9 \%$ of participants think that this online training need to be implemented again.

\section{CONCLUSION}

Online microcontroller training can be done, using the Arduino Uno which is designed simply for beginners. This online training trial proves that there are no significant problems in the implementation of online practicum for microcontroller learning with $92.9 \%$ of participants stating that it is very possible for this online training to be held again. Project-based learning method is also easier to implement with the existence of tinkercad.com, learning the practice of microcontroller assembly can also be done independently by students, which means that the Palembang Aviation Polytechnic has implemented the mandate of the characteristics of vocational learning, namely the studentcentered learning model. Students can simulate many times before real-life practice is 
implemented. The use of Tinkercad is also very economical and inexpensive, because it is based on an open-source website so it is very suitable for use by students.

\section{REFERENCES}

Walid, M. I. (2017). Pengembangan Media Pembelajaran Interaktif Berbasis Geogebra dengan Model Pengembangan ADDIE(Analysis, Design, Development, Implementation, Evaluation)pada Materi Geometri Kelas XI MIA SMA Negeri 3 Takalar. Retrieved from repositori.uinalauddin.ac.id.

Politeknik Penerbangan Palembang. (2020). https://lms.poltekbangplg.ac.id/.

Tinkercad. (2020). tinkercad.com. Diambil kembali dari https://www.tinkercad.com/dashboard?ty pe $=$ circuits\&collection $=$ designs

Arduino Indonesia.

(2018). www.arduinoindonesia.id. Diambil kembali dari

https://www.arduinoindonesia.id/2018/0 7/software-arduino-ide.html

Amalia, D. (2020). Modul Elektronika dan Digital Diploma VI Teknologi Rekayasa Bandar Udara. Palembang.
Dick \& Carey. (2005). ADDIE Learning Development.

RISTEKDIKTI. (2016). Panduan Penyusunan Teknologi Pembelajaran Pendidikan Tinggi Vokasi.

Arduino. (2015). arduino.cc. Diambil kembali dari

https://www.arduino.cc/en/guide/environ ment

Nizam, T. B. (2020). Potret Pendidikan Tinggi di Masa Covid-19. Direktorat Jenderal Perguruan Tinggi.

Intelligence, M. (2020). Diambil kembali dari www.mordorintelligence.com:

https://www.mordorintelligence.com/ind ustry-reports/smart-airport-market

Research and Markets. (2020). Diambil kembali dari www.globenewswire.com: https://www.globenewswire.com/newsrelease/2020/03/02/1993466/0/en/Global -Smart-Airports-2-0-3-0-4-0-IndustryInsights-2020-2025.html

Wikipedia. (2020, November 19). Diambil kembali dari wikipedia.org: https://en.wikipedia.org/wiki/Internet_of -things 